Journal of Ancient Philosophy Vol. II 2008 Issue 1

\title{
O Logos peri philias. Notas sobre a natureza e os propósitos dos livros VIII - IX da Ética Nicomaquéia
}

Carlo Natali (Cà Foscari)

After a general discussion of the structure of $N E$, the author examines in more detail the structure of Books VIII-IX. In the following pages the problem is tackled of a possible independent origin of the treatise on friendship. Nothing in the preceding books hints to such an extended discussion of friendship. However, in the treatise itself there are connections to the preceding books of the $N E$, but, curiously enough, they are limited to the book IX. At the end of the paper the author advances the hypothesis that Aristotle wanted to widen the narrow view of philia discussed by Plato in the Lysis and to arrive to a general discussion of non-hostile relationships in the city.

Nesta comunicação, iniciaremos fazendo algumas observações sobre a natureza literária e filosófica dos tratados éticos de Aristóteles, para passar em seguida a uma descrição mais detalhada da seção da Ética Nicomaquéia (doravante $E N$ ) que é dedicada à amizade. ${ }^{1}$

I. A Ética Nicomaquéia em geral. Sua natureza epistemológica.

Em sua Carta sobre o Humanismo de 1947, Heidegger apresentava o nascimento da ética como um dos frutos e, ao mesmo tempo, um dos sintomas da decadência do pensamento e do esquecimento do ser:

“A 'ética' aparece pela primeira vez com a 'lógica' e a 'física' na escola de Platão. Estas disciplinas nascem na época em que o pensamento se torna 'filosofia', a filosofia epistêmê (ciência) e a própria ciência, assunto de escola e de exercício escolar". ${ }^{2}$

${ }^{1}$ Os parágrafos centrais deste ensaio foram publicados, sob uma forma ligeiramente modificada, no volume editado por E. Vegleris, Cosmos et psychè. Mélanges em homenagem de J. Frère, Hildesheim 2005, pp. 211-228, sob o título de Le premier traité d'éthique. Remarques sur la nature et les desseins de l'Ethique à Nicomaque d'Aristote.

${ }^{2}$ Tradução de R. Munier, Paris 1964, p. 143. 
Com a expressão in der Schuhle Platons, Heidegger designava certamente Aristóteles, embora não o nomeasse explicitamente. Com efeito, entre os discípulos de Platão, somente Aristóteles escreveu logoi peri hêtikês e ele é universalmente reconhecido como o fundador da lógica. Algumas linhas adiante, ademais, Heidegger opõe as tragédias de Sófocles às lições de Aristóteles sobre a ética, em desfavor completo destas últimas. Ainda que, em outros textos, Heidegger demonstre muita consideração pela $E N$ de Aristóteles, este juízo drástico sobre a ética aristotélica é interessante. Ele resulta provavelmente de um erro de perspectiva, que consiste em ler a $E N$ como se tratasse de um escrito de ética moderna, à maneira das obras de Kant e de Moore.

Porém, é absolutamente certo que Aristóteles tenha sido o primeiro a, em pleno século IV aC, querer escrever um tratado de ética, isto é, realizar algo comparável à redação da Ética de Espinosa, da Fundamentação de uma metafísica dos costumes de Kant ou dos Principia ethica de Moore, fazendo abstração da inevitável diferença ligada às épocas e aos conteúdos filosóficos? ${ }^{3}$ Queria realmente Aristóteles escrever uma pragmateia, um tratado, que pudesse dar os fundamentos da ética como ciência à maneira pela qual os princípios da filosofia primeira como ciência do ser são fundamentados na Metafísica e os da filosofia segunda como ciência do devir o são na Física? O filósofo italiano Benedetto Croce já duvidava disso e, com sua falta de atenção costumeira em relação ao mundo antigo, condenava a $E N$ como uma mistura de ética e de preceitos morais:

“A mistura de conceitos filosóficos com conceitos empíricos e com regras é um defeito comum a quase todos os tratados de filosofia da prática, a começar pela Ética Nicomaquéia, a qual, ainda que altamente filosófica em determinados pontos, poderia, em sua maior parte, encabeçar a história dos livros de moralistas e dos livros de preceitos, antes que a história da ética". ${ }^{4}$

\footnotetext{
${ }^{3}$ Kant, no prefácio da Fundamentação (1785), buscava elaborar uma filosofia moral pura, isenta de tudo o que provém da antropologia e que tratasse da idéia comum de dever e de leis morais (na tradução italiana de P. Chiodi, Roma-Bari 1970, p. 5); Moore não se propõe um objetivo muito diferente, séculos mais tarde, em seus Principia ethica (1903): no prefácio à primeira edição deste volume, ele afirma que, com "este título à maneira de Kant", pretende fornecer os prolegômenos a toda futura ética que queira constituir-se como ciência, isto é, em outros termos, quer descobrir quais são os princípios fundamentais do pensamento ético (G.E. Moore, Principia ethica, Londres 1903, p. 3).

${ }^{4}$ Cf. B. Croce, Filosofia della pratica, economica ed etica (1909), ed. M. Tarantino, Bibliopolis, Nápoles 1996 (Edizione nazionale delle Opere di B.C.), p. 114, cf. p. 52; sobre esta opinião de Croce, cf. N. Matteucci, La filosofia della pratica in Benedetto Croce, in E. Berti (ed.), Tradizione e attualità della filosofia pratica, Gênova 1988, p. 95-108; convém lembrar aqui que o maior filósofo italiano do séc. XX, G. Gentile, tinha um grande interesse pelos problemas de filosofia prática; cf. Genesi e
} 
Para Croce, com efeito, a idéia de uma «filosofia prática» contém uma contradição nos termos e o que pode com direito ter lugar no campo filosófico é somente uma filosofia da prática, um estudo especulativo do momento da ação do qual ele fornece a teoria transcendental; a casuística, seja ela de Aristóteles ou a do séc. XVII, está fora do campo da filosofia.

Com efeito, segundo uma opinião antiga, a $E N$ é o tratado no qual, pela primeira vez na história do pensamento ocidental, a ética foi estudada de modo «científico», isto é, com base no método descrito nos Analíticos. É a posição dos comentadores dos séc. XVI - XVII como Johannes Magirus (também chamado de Johannes Austriacus, 1537-1614), que considera que Aristóteles procede de modo analítico ao definir inicialmente a felicidade em suas linhas gerais, esclarecendo então progressivamente as noções necessárias à compreensão desta primeira definição, para finalmente voltar à felicidade no final da obra, de modo a concluir uma discussão "quodammodo circularis et perinde perfecta", Esta interpretação tradicional não é inteiramente falsa. A isso, porém, retornaremos em outra ocasião.

Nós a encontramos ainda, no final do séc. XIX, em um comentário ainda em uso entre os eruditos contemporâneos: as Notes de Stewart. Segundo este autor, com efeito, o fato de a $E N$ começar por uma proposição geral ("cada arte e cada investigação, assim como cada ação e cada escolha, ao que parece, perseguem um certo bem", 1094a1-2), assim como a Metafísica e outras obras de Aristóteles, prova que este tratado segue um método científico, pois Aristóteles poria no início da obra a causa final da ação humana e tudo que deriva diretamente dela, até a tese segundo a qual o bios theôrêtikos é o critério moral com base no qual se avaliam todas as ações humanas e toda a ética. ${ }^{6}$

Assim como a interpretação sistemática tradicional da Metafísica foi seguida por uma interpretação "dialética", o mesmo ocorreu para a EN. Quem iniciou esta tendência no início do séc. XX foi Burnet: ele pôs em evidência as relações estreitas que existem entre o

struttura della società. Saggio di filosofia pratica, in Opere IX, Florença 1987, p. 50-51, onde critica a idéia de uma consideração puramente teórica dos problemas éticos.

${ }^{5}$ Io. Magiri corona virtutum moralium, universam Aristotelis... Ethicen exacte enucleans... adjecto ubique Aristotelis contextu graeco-latino..., ed. R. Walker, Oxford 1942, p. 8 (original: Frankfurt am Main 1628).

${ }^{6}$ J. A. Stewart, Notes on the Nicomachean Ethics of Aristotle, Clarendon Press, Oxford 1892, repr. Bristol 1999, vol. I p. 1-6. 
método da filosofia primeira e os procedimentos lógicos descritos por Aristóteles nos Tópicos; daqui veio a idéia:

- que Aristóteles procede a partir de um "starting-point" que é somente uma verdade geral e vaga, e não um princípio geral e necessário que tem valor de axioma;

- que o princípio primeiro da ética foi obtido com base em uma série de argumentações através de opiniões reputadas ou endoxa;

- e que o resto da ciência prática da ética é composta de proposições que são válidas unicamente "nas mais das vezes", as quais admitem exceções. ${ }^{7}$

O longo período da crítica evolucionista, que se dedicou inteiramente a dissecar o texto das éticas de Aristóteles para encontrar nelas vestígios de diferentes fases de uma evolução do platonismo a uma forma de "empirismo" (ou vice-versa), uma evolução sempre pressuposta, mas jamais definitivamente provada nem descrita em suas diferentes fases, apresenta sinais de esgotamento no debate sobre o método da EN. Constata-se como é fraca a compreensão do método de Aristóteles nos comentários de inspiração puramente evolucionista, como o de R.-A. Gauthier e J.Y. Jolif. Eles afirmam que o método na ética resulta de uma "confusão que torna seu pensamento obscuro e precário". ${ }^{8} \mathrm{~A}$ atenção foi igualmente desviada da estrutura geral da obra, de seus pontos fortes e de suas fraquezas manifestas pelo longo debate que remonta à segunda metade do séc. XIX e que incide sobre a questão de saber se a $E N$, como a conhecemos, foi estruturada pelo próprio Aristóteles ou se foi fruto de um editor posterior que reuniu em uma única obra uma serie de logoi separados ${ }^{9}$ cujo tema era a ética ${ }^{10}$.

A questão que é preciso responder antes mesmo de tomar posição sobre a atualidade do pensamento ético aristotélico é a seguinte: a $E N$ de Aristóteles é realmente um

${ }^{7}$ J. Burnet, The Ethics of Aristotle, London 1900, p. XXXIX-XLIV. Sobre o uso dos métodos dialéticos na EN, ver também E. Berti, Le ragioni di Aristotele, Roma-Bari 1989, p. 126-139.

${ }^{8}$ R.-A. Gauthier - J.Y. Jolif, L'Ethique à Nicomaque, intr. trad. e com., Paris-Louvain 1959, 1970², p. 23-26.

${ }^{9}$ No catálogo de Diógenes Laércio V 22-28 estão listadas as seguintes pragmateiai: Do prazer, Do bem, Proposições sobre a virtude, Das paixões ou da cólera, Ética, Do melhor, Paixões, Do prazer, Do voluntário, Do belo, Dos atos justos, bem como algumas coletâneas de teses éticas de diferentes filósofos e sábios.

${ }^{10}$ As principais posições sobre este problema foram resumidas por I, p. 61-98 ; ver também, mais recentemente, o artigo de R. Bodeüs, Contribution à l'histoire des oeuvres morales d'Aristote: les Testimonia, "Revue Philosophique de Louvain" 71 (1973), p. 451-467, e nossa Introduzione a Aristotele, Etica Nicomachea, trad. introd. et notes de Carlo Natali, Roma-Bari 1999, 2001³ , p. III-VII. 
tratado de ética no sentido corrente do termo? E se não for o caso, de que modo ela opera? Que tarefas ela se propõe? ${ }^{11}$ Ao longo dos últimos anos, muitos estudos sublinharam a diferença, do ponto de vista teórico, entre as preocupações filosóficas de Aristóteles e as dos filósofos modernos; basta citar aqui os nomes de Gadamer, Annas, Broadie. Porém, estes estudiosos não se interessaram pela composição da $E N$ e não buscaram compreender de que modo este tratado foi construído nem quais intenções guiaram Aristóteles no modo como usou seu material. As últimas análises da estrutura e da composição da $E N$ remontam à época da crítica genética e visam a tentar estabelecer a cronologia relativa dos diferentes textos ou a descobrir as passagens duplas ou interpolações. Contudo, elas correm o risco de perder de vista a coerência do conjunto em proveito da análise das diferenças de detalhe. Reexaminemos, portanto, os principais dados.

\section{Particularidades da discussão contida na $E N$}

Alguns aspectos da EN podem parecer desconcertantes para um leitor moderno: largas seções do livro são dedicadas a problemas como a descrição das virtudes particulares, como a coragem, a temperança ou a generosidade (1115a4 - 1128b35, cerca de treze páginas da edição Bekker para um total de oitenta e sete páginas), a distinção dos diferentes tipos de relações de amizade (1155a1 - 1172a14, dezessete páginas da edição de Bekker), ou questões particulares sobre a felicidade hoje obsoletas, como a de saber se devemos dizer de alguém que ele é feliz ainda em vida ou se só devemos dizê-lo feliz depois de sua morte, e questão se a felicidade é algo digno de elogios ou não (1099b9 - 1102a4, três páginas Bekker). Por conseguinte, mais de um terço da $E N$ pode parecer pouco estimulante para um leitor sem interesse pela perspectiva histórica. São dedicadas a temas que dizem respeito a uma fundação da ética no sentido moderno unicamente certas seções da $E N$ e não é um acaso se são as seções mais discutidas e mais comentadas pela literatura crítica : a primeira parte do livro I, que identifica o bem supremo à felicidade (1094a1 - 1099b8); a parte final do livro X, que identifica a felicidade perfeita à vida contemplativa (1177a12 1178b32); a que concerne ao problema do caráter voluntário da ação (1109b27 - 1115a3) ; a

\footnotetext{
${ }^{11}$ Uma crítica geral da possibilidade de comparar as obras filosóficas dos antigos às dos modernos encontra-se em G. Cambiano, Il ritorno degli antichi, Roma-Bari 1988, p. IX. Gostaríamos de chegar aqui a uma conclusão menos cética, a despeito da diferença fundamental que separa o modo de filosofar de Aristóteles do de Moore nos Principia.
} 


\section{Journal of Ancient Philosophy Vol. II 2008 Issue 1}

discussão sobre a justiça, estudada pelos modernos essencialmente nos marcos da filosofia do direito (1129a3 - 1138b13); a que concerne à sabedoria (1138b15 - 1145a11); a seção sobre a fraqueza da vontade, que é discutida essencialmente pelos filósofos anglófonos (1145a15 1152a33, com uma maior atenção à parte inicial até 1147b17) e, enfim, as duas discussões sobre o prazer (1152a34 - 1154b34 e 1172a15 - 1176a29). Portanto, somente uma parte da EN parece interessante para um leitor moderno que se dedica aos problemas contemporâneos de fundamentação da ética.

Se abordarmos sem preconceitos a leitura da $E N$ tal como ela nos foi transmitida pelos manuscritos da Idade Média, parece evidente que a divisão em livros não respeita a estrutura do conteúdo.

O tema inicial, a identificação do bem humano supremo à felicidade, concluise no capítulo 12 do livro I; do capítulo 13 deste livro até o capítulo 9 do livro II (com exceção do capítulo 7), a discussão porta sobre a virtude em geral; o livro III contém dois argumentos bem distintos: a discussão sobre o voluntário e o início da discussão sobre as virtudes particulares, que continua ao longo do livro IV e se conclui no livro V, que é inteiramente dedicado a uma única virtude ética, a mais importante, a justiça. O livro VI tem um argumento unitário, a sabedoria. É com este texto que termina a discussão sobre as virtudes.

O livro VII apresenta-se como um novo ponto de partida; Aristóteles diz explicitamente:

"Após isso, precisamos estabelecer, tomando um outro ponto de partida, que, em matéria de moralidade, as atitudes a evitar são de três espécies" (1145a15-16 : met a; de; t a ut a lekt eon, a[Ihn poihsamenou" ajchn, otgi twh peri; ta; hgh feukt wh tria est in ei $\not h)$.

A expressão "tomando um outro ponto de partida" indica que a longa seção central da $E N$, dedicada às virtudes como componentes da felicidade, foi concluída e que tem início uma série de novas discussões. ${ }^{12}$ Com efeito, o livro VII trata de dois temas : as disposições reprováveis de caráter, como a fraqueza da vontade e a bestialidade, e o prazer.

O livro VIII inicia um tratado sobre a amizade que se prolonga sem interrupção até o fim do livro IX; a cesura entre os dois livros é particularmente infeliz, pois intervém em plena discussão sobre as causas das disputas entre amigos; voltaremos a este ponto. Também

${ }^{12}$ Cf. G. Ramsauer (ed.) Aristotelis Ethica Nicomachea, Leipzig 1878, p. 424; Burnet, p. 288; Gauthier, p. 583 e p. 587. 
o livro X contém argumentos distintos: o prazer, a identificação da felicidade perfeita à vida contemplativa e os problemas da passagem à prática.

Portanto, à exclusão dos livros V e VI, nenhum livro da $E N$ foi dedicado a um único argumento que comece e termine com ele e a divisão em livros, que está ligada ao tamanho de um rolo de papiro, não corresponde à divisão dos temas da $E N .{ }^{13}$ Exemplos similares não faltam em outras obras de Aristóteles, mas é unicamente na $E N$, de nosso conhecimento, que este fenômeno é tão invasivo; é preciso pensar em uma gênese particularmente complexa e movimentada da obra, na qual os tratados de tamanho igual foram dedicados a temas de desigual importância.

Quanto à sucessão dos argumentos, uma análise clara da estrutura geral da $E N$ nos foi dada no séc. XIX por A. Grant e não nos parece que haja muito a acrescentar a seus resultados. Segundo a análise de Grant, o discurso que começa no livro I continua até o livro IV sem obstáculo ou interpolação: a análise é fluida, a argumentação é coerente. Por outro lado, é provável que o fim do livro IV tenha sido perdido. Os três livros V, VI, VII foram igualmente escritos de modo contínuo, mas em um estilo diferente do dos livros precedentes, e eles são também comuns à $E E$, na qual formam os livros IV a VI; provavelmente faziam inicialmente parte da EE. A eles dá seguimento o grupo dos livros VIII-IX, que constituem um todo unitário, e o livro compósito X, que conclui o tratado retomando temas do livro I. Segundo a análise de Grant, do ponto de vista do desenvolvimento lógico e argumentativo do discurso, o conjunto dos quatro primeiros livros aparece como um bloco notavelmente coerente e unitário, bem articulado e logicamente estruturado. Com efeito, como confirmam outros críticos, os primeiros livros foram manifestamente escritos em um estilo elegante, distantes da aridez e da obscuridade de numerosas seções da Metafísica, e possuem em particular refinamentos estilísticos. ${ }^{14}$ Não parece que a $E N$ tenha sido escrita como um bloco único e completo. Por outro lado, é inegável que um elo conceitual muito forte liga o livro I ao livro $\mathrm{X}$ e que isso confere certa unidade ao conjunto.

É igualmente verdadeiro que uma forte aparência de cientificidade e de objetividade foi dada à $E N$ pelo tom positivo pelo qual Aristóteles exprime suas teses e pela

${ }^{13}$ De mesmo modo, a divisão em livros da República de Platão corresponde somente às vezes às principais articulações da argumentação de Sócrates, o que ocorre essencialmente nos livros centrais.

${ }^{14}$ Cf. A. Grant, The Ethics of Aristotle, London $1874^{3}$ vol. I, p. 42-43; Burnet, p. 9; Dirlmeier, Aristoteles. Nikomachische Ethik, üb. u. komm., Berlin 1959, p. 265. 
ausência de toda referência à experiência individual própria. Aristóteles utiliza geralmente a expressão "dizemos" (legomen, eipomen, etc.) e não se sabe em que medida é a comunidade de pesquisa constituída pelo mestre e por seus discípulos que é designada ou até que ponto a primeira pessoa do plural pode ter sido utilizada por modéstia, substituindo um «eu» que toma partido e que é caro à produção moralista tradicional. O próprio Protréptico está singularmente desprovido de referências à subjetividade de Aristóteles.

Ao contrário, referências constantes ao eu são encontradas em Xenofonte (Mem. I 1 1: pollakis ethaumasa; IV 8 11: hemoi men dê, toioutos hôn egô diêgemai) e nos discursos de Isócrates, nos quais o «eu» está freqüientemente presente (cf. por exemplo $A d$ Nicoc. 2: hêgesamen d'an genesthai tautên kallistetên dôrean; Antid. 2: egô gar eidôs enious tôn sophistôn blasphemountas peri tês hemês diatribês etc.). Mesmo em Platão a subjetividade de Sócrates é posta em primeiro plano, sobretudo na Apologia, mas também em numerosos outros textos, como, por exemplo, na célebre passagem do Fédon sobre as causas (96a6: egô gar... ô Kebês, neos ôn etc.). ${ }^{15}$ Neste sentido, a $E N$, bem como a EE, parecem marcar uma virada na história da reflexão antiga sobre a ética, ao passar da exposição de uma experiência pessoal a uma tentativa de definir objetivamente a disciplina. Vejamos as coisas em detalhe.

\section{Particularidades do estilo científico da $E N$}

Começaremos por desenvolver algumas observações sobre a estrutura geral do tratado e por mostrar alguns aspetos do estilo. Mais adiante passaremos a comparar os resultados desta análise com os dados oferecidos pelos livros que tratam da amizade.

O capítulo I 1 (1094a1 - 1095a11) constitui um proêmio à obra inteira, como o diz o próprio Aristóteles no final da passagem, ao resumir os argumentos desenvolvidos. Em seguida, no início de I 2, Aristóteles indica ao leitor qual procedimento ele deve seguir:

\footnotetext{
${ }^{15}$ Um século antes e a muitos quilômetros de distância, Confúcio, em seus Diálogos, não deixava de sublinhar sua experiência pessoal e sua posição própria no mundo quando ensinava sua ética a seus discípulos, e o "wú" (eu, me) está freqüentemente presente, sobretudo no livro VII, que possui um conteúdo amplamente biográfico; ver, por exemplo, o início de VII 1: "eu transmito, e não inovo ... eu ouso me comparar ao nobre Peng"; VII 16: "eu gostaria de dispor ainda de alguns anos" ; VII 19: "não conheço as coisas de modo inato", etc. (segundo a tradução de Lippiello).
} 
"Digamos, retomando o início e dado que cada conhecimento e cada escolha tendem a um certo tipo de bem, qual é este bem, que sustentamos ser o que a política persegue, e qual é o bem prático mais elevado" (1095a13-16).

E Aristóteles começa assim a tratar do problema posto, a saber, qual é o bem humano supremo e qual é objeto da "política". Uma breve digressão sobre o método lógico a utilizar na investigação dos princípios práticos suscita, no início de I 3, uma nova indicação destinada a evitar que o leitor perca o fio da argumentação:

"Nós, ao contrário, retomamos ali onde havíamos desviado" (1095b14). ${ }^{16}$

A partir daqui recomeça a crítica das opiniões correntes, que compreende também uma vasta discussão bem articulada sobre a idéia de bem em Platão (I 4). Ao final da passagem, aparece a idéia que a ética deve estar voltada à prática e não ao puro conhecimento:

"É difícil compreender em que um tecelão ou um construtor seria avantajado em sua arte por conhecer o bem em si, ou de que modo quem contemplou a idéia mesma de bem poderá tornar-se melhor como médico ou como estratego. É evidente, com efeito, que o médico não leva em conta a saúde no absoluto, mas a do homem, e, mais ainda, talvez, a saúde deste homem, pois ele cura os indivíduos tomados separadamente" (1097a8-13).

Feita a crítica das opiniões reputadas, Aristóteles indica de novo a seu público o percurso que ele tem a intenção de percorrer:

"Voltemos ao exame do bem investigado, se é que existe" (1097a14-15).

A frase põe fim à discussão das opiniões sobre a felicidade e começa a discutir a noção de bem como fim supremo. Após algumas palavras, Aristóteles explica de novo a seu público o percurso que está percorrendo:

"Mudando de abordagem" ${ }^{17}$, o discurso volta ao mesmo ponto, que devemos nos esforçar por tornar ainda mais claro" (1097a24-25).

Portanto, Aristóteles indica a cada mudança de discurso o percurso que está fazendo e conduz seu ouvinte de um argumento a outro como se o tomasse pela mão. Ele insiste bastante no fato que o objetivo do desenvolvimento argumentativo é prático e não

${ }^{16}$ F. Susemihl (ed.), Aristotelis Etica Nicomachea, Leipzig 1882, considera, em seu aparato crítico, esta frase como inautêntica, mas não dá razões; ele não foi seguido nem por Bywater nem por Apelt; Gauthier, cit., p. 20, duvida de sua autenticidade, mas se baseia em suas técnicas de reconstrução do texto caracterizadas pelo deslocamento de seções inteiras do texto de um lugar a outro.

${ }^{17}$ Os comentadores estão divididos a respeito do sentido do termo met abainwn, e alguns propõem compreendê-lo como "passando por uma alteração" (Ramsauer, Burnet, Dirlmeier, Tricot), ouros como "progredindo passo a passo" (Stewart, Gauthier, Zanatta); mas a frase que segue: "devemos nos esforçar por tornar ainda mais claro" nos parece tornar preferível a primeira interpretação. 
somente cognitivo. É igualmente típico destes primeiros livros da $E N$ a tendência de introduzir novos conceitos de modo quase imperceptível no interior de discussões particulares, sem dar imediatamente uma definição oficial, que ocorre somente bem mais tarde no tratado. Alguns exemplos:

- O que acontece no capítulo I 1 a respeito do conceito de "bem como fim supremo" e "como objeto da política"; o mesmo ocorre com inúmeros outros conceitos.

- É dito pela primeira vez, na discussão sobre o ergon, a função típica do homem, que a ação humana deve produzir-se segundo a razão (kata logon, 1098a7); este tema é em seguida retomado no livro II em 1103 b 33, mas a explicação será dada somente no livro VI.

- A noção de "justo meio" aparece em 1104 a 26 durante a discussão de um ponto particular, a saber, o problema do modo pelo qual as virtudes são adquiridas e o fato de os hábitos serem produzidos e destruídos pelas mesmas ações, e esta noção é definida somente em II 5.

- A idéia de os atos virtuosos deverem ser realizados com base em uma escolha é afirmada por Aristóteles, pela primeira vez, durante a discussão de uma objeção sofística: como é possível realizar atos justos sem ser ainda justo (1105 a 17-33) e ela é discutida somente no livro III.

Os comentadores observaram este modo de proceder por pequenos passos, quase imperceptíveis, que é uma maneira retoricamente eficaz de fazer o público aceitar mais facilmente as teses propostas. Alguns comentadores modernos, como Grant e Ramsauer, sustentam corretamente que Aristóteles procede deste modo aparentemente pouco linear no intuito de convencer com maior eficácia. Ramsauer o afirma de modo explícito: usu conviceremur, prudentem ita Aristotelem in docendo progressus est. ${ }^{18}$

Com efeito, uma obra como a $E N$, endereçada a um público tão vasto, deve utilizar para convencer métodos retóricos mais eficazes do que a pura coerência dedutiva na passagem de um conceito a outro, porque um procedimento exclusivamente lógico corre o

\footnotetext{
${ }^{18}$ Ramsauer, cit., p. 95-99: é estranho, observa, que questões tão importantes sejam introduzidas de modo quase fortuito na discussão de uma simples aporia ; de outro lado, ele acrescenta, p. 109, que se, em geral, Aristóteles procede percaute et modestius, por vezes, ao contrário, ele introduz conceitos novos ex abrupto, como na definição da virtude ética, em 1106b36 - 1107a2, onde surgem novos conceitos, por exemplo a idéia que o phronimos é a medida do justo meio. Indubitavelmente, porém, o primeiro modo de proceder prevalece na $E N$.
} 
risco de aborrecer um certo tipo de público que não se dedica à filosofia. É o que o próprio Aristóteles observa na Metafísica:

"O sucesso das lições depende do caráter [dos ouvintes]; desejamos que nos falem do modo como estamos habituados e as coisas que vão para além do uso não parecem as mesmas, mas parecem excessivamente difíceis de serem compreendidas e estranhas, por falta de hábito (...). Portanto, se algumas pessoas não aceitam os termos ditos quando não se fala com um rigor matemático, outras, ao contrário, não os aceitam se não se dá exemplos, e outros ainda querem que se cite o testemunho do poeta" (994b32-995a8).

E Aristóteles o repete n Retórica:

"[em filosofia,] a dedução não é fácil de ser seguida por causa de sua extensão, supondo que quem julga é uma pessoa simples” (1357a10-12).

Os procedimentos que indicamos nos fazem pensar que a intenção de Aristóteles não era somente fundar os princípios primeiros da ética, como também, e talvez sobretudo, convencer seu público. O objeto deste esforço para convencer só pode ser a aceitação de uma doutrina ética particular, a escolha de um modo de vida virtuoso no qual a parte principal do esforço é dedicada à filosofia, isto é, o bios theôrêtikos. Ou seja, o modelo de felicidade perfeita descrito no livro final da $E N$. A $E N$ parece, portanto, estar destinada não somente a fundar os principais conceitos da ética, mas também a exortar a um novo modo de vida.

\section{Relações entre a EN e o Protréptico}

Pode-se dizer que, por seu estilo e por seu modo de apresentar os argumentos, o livro I da EN mostra semelhanças evidentes com o Protréptico. O modo de expor os argumentos, assim como o fim prático são elementos comuns às duas obras. ${ }^{19}$ Conduzir o leitor pela mão através das articulações do discurso é, pois, um elemento típico dos capítulos

\footnotetext{
${ }^{19}$ A presença de elementos do Protréptico na EN foi mostrada por vários comentadores e I. Bywater, ao mesmo tempo o iniciador da redescoberta do Protréptico e editor da $E N$, já escrevia : "The thought and style of the fragment remind one at every turn of the writer of the Ethics" (On a lost dialogue of Aristotle, Journal of Philology II, 1869, p. 67). Mais recentemente, ver Dirlmeier, cit., p. 277-278; Gauthier, cit., p. 32 e 67 ; para o livro X, a conexão entre as duas obras foi sugerida por E. Berti (ed.), Aristotele, Esortazione alla filosofia (Protreptico), Pádua 1966, Nápoles 19942, p. 95-97 e 116-125, e também por G. Romeyer Dherbey, Vie bienheureuse et philosophie. Les traces du Protreptique dans le livre X de l'Ethique à Nicomaque (1975), publicado em La parole archaïque, Paris 1999, p. 200-220 ; ver, porém, as reservas de R. Bodeüs, Le philosophe et la cité, Paris 1982, p. 141-147.
} 
6 a 12 do Protréptico de Jâmblico, onde se reconhecem, segundo todos os comentadores, extratos do Protréptico de Aristóteles. ${ }^{20}$ No Protréptico de Jâmblico, encontramos expressões muito similares às da $E N$ que acabamos de ver; por exemplo, é dito:

"Retomando do início (ahwqen de; ajcomenoi), partamos do propósito da natureza e procedamos do seguinte modo" (p. 49, 1-3 Pistelli = 79, 7-8 Des Places).

A expressão ałhwqen de;ajcomenoi que aparece aqui é característica da $E N^{21}$ e não se encontra em nenhum outro autor do séc. IV, salvo uma única vez em Platão, nas Leis $781 \mathrm{~d} 9-\mathrm{e} 1:$

"não se surpreendam se pareço tratar da coisa tomando início de certo modo mais acima (a hwqea p oqen ej ic eir eih)".

Numerosas são as passagens nas quais Aristóteles pontua suas demonstrações com indicações sobre o modo como ele procede e sobre as articulações conceituais de sua argumentação, precisamente como o vimos fazer na $E N$. Eis a série dos outros casos mais significativos:

"Visto que desejamos todos as coisas úteis e vantajosas, é preciso mostrar que estas duas características pertencem à prática da filosofia e que a dificuldade da aquisição é inferior à grandeza do ganho" (37, 22-26 Pistelli = 68, 14-18 Des Places).

"No que concerne ao caráter vantajoso e à importância da filosofia, consideramos que fornecemos uma demonstração suficiente; porém, no que toca à razão pela qual a aquisição desta última é muito mais fácil que a dos outros bens, pode-se persuadir-se pelo que segue' (40, 13-16 Pistelli = 70, 20-22 Des Places).

"Ademais, é bom relembrar a tese proposta partindo do modo comum de pensar, a partir do que é claro para todos" (45, 4-7 Pistelli = 75, 14-15 Des Places).

"Pode-se obter a mesma conclusão partindo igualmente das considerações seguintes, examinando-se com atenção a vida humana" (47, 5-6 Pistelli = 77, 12-13 Des Places).

"E, se for preciso argumentar não somente considerando cada parte, mas também partindo de mais acima (a hwqen) e considerando a felicidade em sua integralidade" (59, 19-21 Pistelli = 89, 7-9 Des Places).

${ }^{20}$ I. Düring, Aristotle's Protrepticus. An attempt at reconstruction, Göteborg 1961; O. Gigon, em Aristotelis Opera, edidit Academia Regia Borussica, Editio altera, III: Librorum deperditorum fragmenta, coll. O.G., Berlin - New York 1987, p. 302b-318b. Seguimos aqui a reconstituição de E. Berti, La filosofia del primo Aristotele, Pádua 1962, Milão 1997², p. 395-485, e id., Esortazione, cit., que segue, contrariamente a outros editores, a ordem dos argumentos apresentada por Jâmblico e considera como autênticas todas as passagens nas quais são postas em evidência as articulações do discurso ; sobre este ponto, O. Gigon concorda com ele.

${ }^{21}$ Cf. EN 1139 b14: aj xamenoi ouh a hwqen, 1144 a 13-14: mikron ahwqen ajkt eon. 
Quanto à origem desta maneira de escrever, outras comparações poderiam ser feitas, não somente com o Protréptico, mas, de um modo geral, com a literatura moral da época de Aristóteles e, sobretudo, com os escritos de Isócrates e Xenofonte. Há certos elementos que aproximam a $E N$ dos discursos de Isócrates e a Ciropedia e os Memoráveis de Xenofonte. Em particular, lhes são comuns:

- o objetivo prático da argumentação,

- o uso de indivíduos reais como modelos a seguir no lugar de leis,

- o fato de proceder por argumentos que são válidos nas mais das vezes,

- a referência constante às opiniões do auditório, que as toma como pontos de comparação para o valor dos argumentos próprios.

Por outro lado, é importante observar que, na $E N$, a insistência sobre o caráter prático da investigação aparece freqüentemente nos livros I e II, como dissemos, e reaparece no final da obra, no livro $\mathrm{X}$, mas está por assim dizer completamente ausente dos livros centrais e, sobretudo, dos que são dedicados à amizade. Em outros termos, ela se encontra nos livros nos quais Aristóteles utiliza o expediente retórico que definimos como consistindo em « conduzir pela mão o leitor » no desenvolvimento de suas argumentações, mas ela desaparece quando este modo de proceder não está mais presente. Daí a impressão que o estilo dos livros I - II e da segunda parte do livro X é muito similar e bem diferente do estilo dos livros centrais. Veremos isso a propósito dos livros sobre a amizade.

5. Os livros sobre a amizade. As duas discussões sobre a amizade.

Temos dois tratados da amizade escritos por Aristóteles: um na EN 1155a11172a14 e outro na $E E$ 1234b18-1246a25. As relações entre os dois tratados são ainda obscuras, embora tenha havido tentativas para esclarecê-las. É a este fim que é dedicado o capítulo 5 do estudo de Rowe $\mathrm{e}^{22}$; ele sustenta que a " $E N$ is the less well ordered of the two works ... in the $E N$ the discussions are entirely disconnected, whereas in the $E E$ they are not" (p. 55), pois ela apresenta os pontos, um após o outro, de modo desconexo, enquanto a $E E$ é

${ }^{22}$ Ch. Rowe, The Eudemian and Nicomachean Ethics. A study in the development of Aristotle's thought, Cambridge 1971, p. 52-60. Outras comparações estão em J. C. Fraisse, Philia. La notion d'amitié dans la philosophie antique, Paris 1974, p. 280-281; M. Pakaluk, Aristotle. Nicomachean Ethics books VIII and IX, transl. and comm., Oxford 1998, p. 229. 
mais coerente e mais bem ordenada. Em sentido contrário, alguns anos mais tarde, Fraisse, em seu estudo sobre a amizade em geral ${ }^{23}$, sustentou que "há na Ética Nicomaquéia uma maior sistematização do pensamento" (p. 284) e que não se pode deixar de perceber «o agrupamento que nela se observa em torno das idéias de justiça e de juízo, de um lado, da perspectiva da análise psicológica, de outra parte, de muitas questões que, na Ética Eudêmia, ficam ainda no nível de problemas de significação ou de casos embaraçosos » (p. 282). A oposição das apreciações é total, o que prova que, tudo sendo considerado, o juízo sobre a organização de um texto é subjetiva.

$O$ juízo de Rowe segundo o qual " $N E$ shows a greater interest in the phaenomena themselves, $E E$ in the classification of phaenomena" (p. 60) é seguramente aceitável, mas, com ele, começa-se somente a esboçar o estudo da questão, como testemunha a declaração no livro recente de R. Bodeüs:

“[As] passagens paralelas [das duas éticas] expõem teses comuns aos dois compêndios. Porém, basta as ler em paralelo para observar que têm em comum somente um fundo comum de idéias e convicções. Estas são, pois, expressas em termos diferentes, isto é, em um estilo próprio a cada compêndio $[=E E, E N]$. Nenhum paralelo é a reprodução perfeitamente literal de seu paralelo e seguidamente a exposição é mais breve ou mais longa em um caso do que em outro... a originalidade de cada obra ... já começa ấ”. ${ }^{24}$

Sobre este ponto, veja-se agora a nota de C. Buffon nesta revista; nesta comunicação, nos ocuparemos unicamente da $E N$.

6. Origem e situação atual do logos peri philias.

Gostaríamos de começar esta parte de nossa intervenção oferecendo uma rápida caracterização do conteúdo dos livros VIII - IX antes de responder à questão que nos colocamos no início: como ocorre que Aristóteles tenha dedicado tanto espaço à discussão sobre a amizade na $E N$, um lugar desproporcional em relação ao que atribuiu a outras discussões?

Em um rápido resumo, pode-se dizer que o desenvolvimento do logos peri philias é o seguinte:

\footnotetext{
${ }^{23}$ Fraisse, p. 282-286. Ele não cita a obra de Rowe, que, de fato, não parece conhecer.

${ }^{24}$ R. Bodeüs, Aristote. Ethique à Nicomaque, tradução, apresentação, notas e bibliografia, Paris 2004, p. 17
} 
1. No início (VIII 1 1155a1-28), Aristóteles apresenta argumentos para demonstrar a importância e o interesse do problema. ${ }^{25}$

2. Em seguida (VIII 2 1155a32-b16), ele passa à discussão de uma série de aporias introdutórias, que manifestamente retirou do Lysis, como: os amigos são semelhantes ou dessemelhantes entre si? Postas de lado as doutrinas cosmológicas como a de Empédocles, ele se limita a pôr problemas limitados à esfera unicamente humana e deste modo dita o programa das investigações que seguem. Será preciso discutir, acrescenta Aristóteles, para saber

- se há uma só forma de amizade ou mais de uma;

- se as formas de amizade são mais do que uma, como pode haver graus de intensidade maior ou menor;

- se a amizade só existe entre homens de bem ou se também entre medíocres e entre homens perversos.

3. A solução destas aporias é mostrada através de uma distinção de significações, como corre seguidamente em Aristóteles (VIII 2-5 1155b17-1157b1). Ele afirma que o "amável" se diz em três sentidos ${ }^{26}$ : é amável o bom, o agradável e o útil, portanto há três tipos de amizade, diferentes por espécie : a amizade do útil, do prazer e a amizade perfeita. ${ }^{27}$ Aqui inicia uma ampla discussão, um pouco repetitiva, sobre os três tipos de amizade comparados entre si e sobre os diferentes grupos sociais que mais tendem aos três tipos de amizade (os velhos: ao útil; os jovens : ao prazer; os bons : à amizade perfeita).

4. A seção seguinte (VIII 6-7 1157b1-1158a36) não tem unidade orgânica; a comparação entre os três tipos de philia já era bem desordenada, mas, ainda, Aristóteles acumula uma série de observações desconectadas e parece fazer uma fenomenologia da amizade. Em termos biológicos, poder-se-ia dizer que está aqui presente uma historia da amizade, não uma de causis amicitiae. Entre os itens discutidos, há a amizade em potência e a amizade em ato, a

${ }^{25}$ A distinção dos capítulos da $E N$ data da Idade Média e pode ser decepcionante; a citamos por vezes por comodidade, sem, porém, lhe atribuir nenhum peso.

${ }^{26}$ Aristóteles não diz que há três objetos que têm, todos os três, a qualidade de serem "amáveis" no mesmo sentido, mas que a amabilidade tem uma origem, e portanto um sentido diferente, nos três tipos de objeto.

${ }^{27}$ Aqui, como se sabe, há diferenças importantes com a $E E$, que distingue não três sentidos de "amável", mas três sentidos de "bem" e estabelece uma relação pros hen entre as diferentes formas de amizade e a amizade perfeita. Nosso propósito não é o de discutir este ponto aqui. Cf. E. Berti, Il concetto di amicizia in Aristotele, in Varii., Il concetto di amicizia nella storia della cultura europea, Merano 1995, p. 102-122. 
necessidade da coabitação, a relação entre amizade (philia) e afeição (philêsis); em seguida, Aristóteles recomeça a discutir questões que já evocou, como as diferenças entre velhos e jovens, e antecipa aporias que discutirá mais adiante, como a do número de amigos que se deve ter. Em suma, um pot pourri.

5. O capítulo VIII 8 (1158b1-28) representa uma virada. Aristóteles resume o conteúdo dos sete primeiros capítulos (b1-11) e acrescenta em seguida que há um outro eidos da philia, o kath'huperochê. Além da «amizade que implica igualdade », há a «amizade que comporta uma superioridade de um partido sobre o outro ». Segue uma longa discussão, que ocupa várias páginas da edição Bekker, indo até 1162b4, que cobre substancialmente todas as relações interpessoais não políticas entre cidadãos livres. Aristóteles fornece exemplos de amizade entre pessoas diferentes, que mostram a quais relações ele quer fazer referência:

"a afeição de um pai a um filho e, de um modo geral, de uma pessoa mais idosa a uma mais jovem, ou ainda a do marido à mulher ou a de uma pessoa que exerce um comando qualquer a um inferior". ${ }^{28}$

6. Dá seguimento à seção da amizade entre desiguais novamente uma seção composta de observações desprovidas de ligação, sem coordenação entre si (VIII 9-10 1158b33-1159b25). Os editores tiveram muita dificuldade também para dividir esta seção em capítulos, pois ela não apresenta uma organização coerente. São tratados problemas de aparência sofística e casuística, como "deve-se desejar ao amigo tanto sucesso a ponto de romper a amizade?" etc.

7. Em seguida (VIII 11-14 1159b26-1162a33), Aristóteles se pergunta como instaurar o ison, a igualdade, entre homens diferentes. Com efeito, sem uma igualdade de certo tipo, a amizade não persiste: portanto, é preciso um tipo de proporcionalidade que mantenha o respeito entre os membros (1158b11-33).

8. Dá seguimento à seção sobre a justiça entre os diferentes tipos de amizade (em VIII 15, 1162a34 - IX 1 1165a35) a análise das reivindicações possíveis de um amigo a um outro e das querelas entre amigos em geral.

9. A discussão sobre a philia se conclui com considerações variadas.

No início, encontramos um exame de algumas aporias (IX 2 1164b22-4, $1166 b 28)$; é um procedimento habitual em Aristóteles, especialmente na $E N .^{29}$ Seria

\footnotetext{
${ }^{28}$ patri;pro," uipn kai; o\{w" presbuterw/pro", newteron, ajdrivte pro," gunaika kai; panti; alcont i pro," ajcomenon (1158b11-14).

${ }^{29}$ Cf. por exemplo EN I, 9-12.
} 
extenuante enumerá-las todas aqui; citaremos somente duas : “deve-se sempre obedecer aos pais ou não?" e "deve-se manter a amizade por alguém que muda de caráter ?"

Encontra-se misturada à discussão das aporias conclusivas uma discussão sobre as formas semelhantes à amizade, como a benevolência e a concórdia (IX 5 1166b29-6, 1167b16). Este exame constitui o paralelo à discussão das formas semelhantes à phronesis, "a perspicácia e o bom juízo", que se encontra no livro VI (11 1142b34-1143a24).

Seguem-se enfim outras aporias, desta vez conclusivas. Convém observar que possuem um forte interesse prático. Mesmo sem repetir continuamente, como fazia no início, que o objetivo do logos é a constituição de bons amigos e não somente o de saber o que é um bom amigo, Aristóteles conclui seu discurso com problemas ligados à casuística prática. Por exemplo: "deve-se amar a si mesmo ou ao amigo?", “o homem feliz terá necessidade de amigos?", “quantos amigos se deve ter?", "é melhor ter amigos na boa ou na má sorte?" (IX 1111b67-12, 1172a14). Estas aporias práticas são semelhantes, em espírito, às que concluem o livro II (9 1109a20-b26), com indicações práticas sobre o modo de se obter o justo meio.

10. O livro IX termina com uma citação poética, no caso, de Teógnis : “das pessoas de bem se recebe bons conselhos" (1172a14 = Theognis v. 35), exatamente como uma citação de Homero concluía o livro XII da Metafísica.

O problema preliminar que salta aos olhos do leitor atento é, como já dissemos, a desproporção da discussão sobre a amizade em relação às outras discussões; já dissemos que o livro VIII inicia um tratado sobre a amizade que se prolonga sem interrupção até o fim do livro IX : às oito páginas dedicadas à identificação fundamental do bem supremo à felicidade (1094a1 - 1102a4, incluindo a longa discussão das aporias conclusivas pouco interessantes de cerca de três páginas, 1099b9 - 1102a4) opõem-se as dezessete páginas dedicadas à amizade, um tema, no cômputo geral, um tanto marginais (1155a1 - 1172a14).

Esta diferença de extensão do tratado sobre a amizade poderia fazer pensar que Aristóteles teria inserido, como que por força, no corpus dos êthikoi logoi um tratado sobre a amizade que, talvez, teria sido composto independentemente. Certas diferenças estilísticas que distinguem os livros VIII-IX do grupo dos livros I-IV poderiam fazer pensar a uma origem independente deste logos. Sobretudo, estão manifestamente ausentes, na EN VIII-IX, as características distintivas que mostramos para os livros I-IV e $\mathrm{X}$ na segunda parte. Não encontramos aqui: 
- nem o fato que Aristóteles indica a cada virada do discurso o percurso que está realizando conduzindo o ouvinte de um argumento a outro como se o tomasse pela mão;

- nem a tendência de introduzir novos conceitos de modo quase imperceptível no interior de discussões particulares, sem logo dar uma definição oficial, que só aparece bem mais tarde no tratado;

- nem uma indicação explícita do objetivo prático da obra.

Este último ponto, todavia, mesmo que não seja afirmado, está bem presente e uma boa parte da descrição dos diferentes tipos de amizade e de aporias próprias ao estudo da amizade tem, como já vimos, um objetivo prático e pretende dar indicações sobre o modo de resolver os problemas que se criam nas relações entre amigos na vida quotidiana. Porém, se examinarmos o texto da $E N$ VIII-IX em busca de indícios de uma redação anterior dos dois livros como um tratado independente, nos encontramos diante do que constitui, para citar uma velha e bela canção dos Talking Heads, a "puzzling evidence”. Com efeito, encontramos no corpo do capítulo indicações que vão tanto em um sentido quanto em outro. Talvez seja esta razão pela qual Dirlmeier sustenta em seu comentário que tentar saber se estes livros eram na origem um tratado autônomo ist unfruchtbar ${ }^{30}$. Vejamos, contudo, os dois tipos de dados contraditórios, partindo dos que indicariam uma origem independente do logos peri philias.

Algumas remissões internas poderiam fazer pensar em uma existência independente da obra, pelo menos em certo período. Por várias vezes Aristóteles utiliza a expressão kaqaper en ajchy eifhtai, "como foi dito no início" para remeter a uma afirmação que foi feita no início do tratado sobre a amizade. Muitas destas remissões fazem referência ao início do livro VIII e não ao início da $E N$ em sua totalidade. Isto induz a pensar que VIII 1 era considerado como o início de um tratado independente e não somente como o início de uma seção particular da $E N$. Vejamos alguns exemplos de remissão:

- a passagem em VIII 11 1159b24-25: "parece bem, como dissemos no início, que a amizade e a justiça têm relação com os mesmos objetos e intervêm entre as mesmas pessoas" remete a VIII 1 1155a22-28: "a amizade parece constituir o elo das cidades e os legisladores parecem parece atribuir mais valor que à própria justiça ... entre os amigos, não é mais preciso justiça, ao passo que, para os justos, é preciso ademais a amizade";

${ }^{30}$ Dirlmeier, p. 508. 
- a passagem em VIII 15 1162a34: "visto que existe, assim como dissemos no início, três espécies de amizade" remete a VIII 3 1156a7: “ter-se-á portanto três espécies de amizade".

- no livro VIII, há varias remissões internas ao mesmo livro (1157b26, 1158a33, 1158b5, 1159a9, 1161b11, 1163b12); similarmente, no livro IX, há várias remissões ao livro VIII (1163b33, 1164a12, 1164a35, 1156b20, 1165b31, 1166b32 [proteron remete a 1155b 27-34]) ou ao próprio livro IX (1165a 2, 1166a 34, 1168b5).

- não há nenhuma remissão de VIII a IX, tanto quanto se pode constatar. ${ }^{31}$

Porém, na lista de Diógenes Laércio, está mencionado, entre os tratados esotéricos, somente um tratado peri philias em um livro $\left(\mathrm{n}^{\circ} 24\right)$; na versão da mesma lista dada por Hesíquio, diz-se que a obra estava composta de três livros. A lista de Ptolomeu elGarib dá a mesma indicação ( $\left.\mathrm{n}^{\circ} 28\right)$. Portanto nenhuma destas indicações corresponde ao tratado que nos foi transmitido. Ademais, não faltam remissões que levam a considerar os livros VIII-IX como a parte de um todo mais amplo ligando a discussão sobre a amizade aos livros da $E N$ que a precedem. Curiosamente, todas estas remissões se encontram no livro IX e não há nenhuma no livro VIII.

No livro IX 9 1169b29, encontramos uma remissão ao início da $E N$ tomada em sua totalidade e não ao início da discussão peri philias: "no início, tínhamos dito que a felicidade é uma atividade", o que remete a EN I 6, 1098a16: "o bem para o homem consiste em uma atividade da alma conforme à virtude", isto é, à definição oficial da eudaimonia ou a I 9 1098b31-33: "há uma diferença importante segundo se coloca o bem soberano na posse ou no uso, em uma disposição ou em uma atividade".

Outro exemplo de mesmo gênero se encontra poucas linhas adiante, em IX 9 1169b32: "se a atividade do homem de bem é virtuosa e agradável nela própria, como dissemos no início" remete a I 9 1099a14: "os que amam as belas ações as acham agradáveis e é característica das ações conformes à virtude serem agradáveis nelas mesmas e também para os que são virtuosos".

\footnotetext{
${ }^{31}$ Poder-se-ia pensar que a passagem X 3 1165b 6, "como dissemos no início, conflitos entre amigos se produzem nas mais das vezes quando eles não são amigos como se crêem ser" remete talvez a VIII $15,1162 \mathrm{~b} 23-25$ : "os conflitos se produzem quando os interessados fizeram um pacto ou o anularam, reivindicando um tipo de amizade que não é o mesmo" (segundo Susemihl p. 279 ; Ramsauer p. 589590 ; S. Broadie - Ch. Rowe, Aristotle. Nicomachean Ethics, Oxford 2000 [Broadie], p. 418), mas, de fato, não se pode dizer que esta passagem se encontra "no início", pois está no fim do livro VIII, após a remissão precedente ç ademais, a correspondência não é perfeita. É, portanto, preferível pensar, como o faz Gauthier (p. 722), que se trata de um acréscimo de um editor posterior.
} 
Outras remissões de IX, igualmente, referem-se ao início da $E N$ :

- IX 2 1165a12: "como dissemos várias vezes, os argumentos relativos às paixões e às ações humanas têm a mesma definição que os objetos de que tratam" remete a diferentes passagens de EN I, entre as quais a primeira é I 1 1094b13 “não se deve buscar o mesmo rigor em todos os argumentos";

- IX 4 1166a12-13: "como dissemos e segundo a opinião de todos, a virtude e o homem virtuoso são a medida de todas as coisas" remete a III 6 1113a32-33 : "o que distingue o homem excelente é que ele percebe em todas as coisas a verdade que elas contêm, sendo para elas como uma regra e uma medida";

- IX 9 1170a14-16, “o que é bom por natureza, já o dissemos, é para o homem virtuoso bom e agradável em si” remete a I 9, 1099a11-13 : "as ações conformes à virtude agradam aos homens que amam a virtude ... e eles encontram gozo nas coisas que são prazeres por natureza".

Somente o livro IX se preocupa em ligar esta discussão ao que precede na $E N$, e o livro VIII não o faz; veremos mais adiante hipóteses sobre a razão deste fato. A própria frase com que se inicia o livro VIII indica também que a discussão sobre a amizade é considerada por Aristóteles como uma parte de um conjunto mais amplo e não constitui, no modo como ela se apresenta atualmente, um logos autônomo:

“Após isso, podemos passar à discussão sobre a amizade; com efeito, a amizade é uma virtude de certo tipo ou não ocorre sem virtude". ${ }^{32}$

A expressão met a; de; t a ut a , após isso, é típica de certos tratados aristotélicos. Na própria $E N$, a encontramos no início do livro VII, em uma passagem que havíamos citado anteriormente:

“Após isso, é preciso dizer, tomando um outro ponto de partida, que, em matéria de moralidade, as atitudes a evitar são de três tipos: vício, falta de domínio, bestialidade". 33

32 meta;de;tauta peri;filia" epoit jah diel qeih: ekti gar ajethuti" h]met jajeth", efi d j ajagkaiotat on eil' t on bion (1155a 3-5).

${ }^{33}$ meta; de; tauta lektern, a [Ihn poinsamenou" archn, obi twh peri; ta; hgh f eukt wh tria ekt in ei th: kakia akrasia qhrioth" (1145a15-17). Segundo a edição de Bywater, é deste modo igualmente que começa o capítulo II 4, 1105b 19: M et a; de; taut a tiveśt in hJajet h; s kept eon. Aqui, Bywater segue o texto do mais antigo manuscrito, $\mathrm{Kb}$; mas a edição Susemihl-Apelt lê, ao contrário, na mesma linha: tivd jej tin hJajeth; ekh" skepteon, seguindo os outros manuscritos principais $(\mathrm{Lb}, \mathrm{Mb}, \mathrm{Ob})$. Apesar da importância do manuscrito $\mathrm{Kb}$, parece-nos preferível reservar esta 
Esta expressão encontra-se igualmente em outros lugares, especialmente em certas obras nas quais Aristóteles examina uma série de noções umas após as outras, sem as dispor em ordem de dependência lógica ou causal ou que estão simplesmente justapostas. Assim começam com a expressão met a; de; t a ut a os livros IV $1120 \mathrm{~b} 12$ (M et a; de; t a ut a peri;t wh pro," to;gemo" kai; o; idion episkepteon) e VIII $1155 b 3$ (M et a; de;t a uta peri; taxew" kai; pw" dei'ejwtah lekteon) dos Tópicos. É desta maneira também que começa o tratado De insomniis 1458 a33 (M et a; de; t a ut a peri; ejup niou ej izht ht eon) e isto constitui um indício importante do fato que os Parva naturalia constituíram durante um certo tempo um tratado único. ${ }^{34}$ Ademais, esta expressão é freqüente nas obras mais descritivas de Aristóteles, como a Historia animalium e a Athenaion politeia ; ela está igualmente presente em outras obras, como a Metafísica, a Física, o De caelo, a Retórica etc., nas quais indica quase sempre a passagem a um outro ponto do discurso, justaposto ao que precede e não deduzido deste último. Desenvolverei este ponto na seção seguinte.

Qual é a razão pela qual Aristóteles, ou alguém em seu lugar, considerou que era oportuno colocar o logos peri philias após a discussão sobre a falta de controle de si, entre as duas discussões sobre o prazer e antes da discussão sobre a felicidade perfeita? Não me parece haver aqui uma relação sistemática entre os argumentos, como Ramsauer já havia observado. ${ }^{35}$ A hipótese de Burnet, segundo a qual a reflexão sobre a philia segue a da phronêsis porque quanto mais profunda for a phronêsis, mais os elos da philia são puros, é muito estranha para ser discutida seriamente; basta observar que o livro VIII não segue o livro VI, que é o da phronêsis, pois entre os dois se encontra o livro VII, com a discussão sobre os estados reprováveis da alma e a discussão sobre o prazer. ${ }^{36}$ A frase final do livro VII, 1154b 32-34, liga, ao contrário, explicitamente a conclusão da passagem sobre o prazer e o início do

fórmula para o início de uma nova investigação e não ao desenvolvimento decisivo de uma investigação já iniciada, o que é o caso de II 4. Ramsauer, p. 99, é da mesma opinião que Bywater.

${ }^{34}$ Sobre este problema, ver atualmente P.-M. Morel, Aristote. Petits traités d'histoire naturelle, trad., introd., notas e bibliog., Paris 2000, p. 10-12.

${ }^{35}$ Ramsauer, p. 503. Não partilhamos a opinião de Dirlmeier, EN p. 509, segundo a qual o elo da discussão sobre a philia com o que precede é organisch pela única razão que ela é um elemento necessário da felicidade. Em primeiro lugar, ela não é necessária, como é dito no início de $E N \mathrm{X}$; ademais, o tema da autarcheia tinha sido tratado na EN I ; enfim, os tipos de felicidade descritos aqui parecem deixar pouco lugar à eudaimonia como exercício da faculdade teorética.

${ }^{36}$ Burnet p. 344-345. 
logos sobre a amizade; ela é considerada como um acréscimo editorial por Aspásio, Ramsauer, Stewart, Gauthier, embora seja considerada como autêntica pelo próprio Burnet e Irwin.

Com efeito, nada nos livros precedentes da $E N$ indicava a necessidade de uma discussão tão ampla da amizade. Ao final do livro IV, uma passagem que anuncia tanto a discussão sobre a justiça no livro V como a discussão sobre o controle de si no livro VII não faz nenhuma alusão à discussão sobre a amizade:

"o controle de si tampouco é uma virtude, mas uma mistura; mostraremos isso na sequiência. Pelo momento, falemos da justiça". 37

Ademais, as alusões que são feitas à philia nas seções precedentes da $E N$ não permitem pressagiar que virá mais adiante na obra um exame tão aprofundado e extenso. Poderíamos distinguir aqui entre as alusões ao fato da amizade, o uso do termo philia em si e para si, e as conclusões que se pode tirar dos dados presentes no primeiro capítulo do livro VIII.

Vejamos em seqüência estes três pontos. Na discussão sobre a eudaimonia coloca-se o problema da autarcheia, que é uma das características próprias do bem supremo; no livro I, Aristóteles concede certo espaço às relações humanas em sua concepção do bem supremo:

"Por o que basta a si mesmo entendemos o que basta não a um homem só, que leva uma vida solitária, mas também a seus pais, filhos, mulher, seus amigos e concidadãos em geral [toi" f ivoi" kai;politai"], visto que o homem é por natureza um animal político" (1097b 8-11).

Porém, ele não acrescenta mais nada. Na discussão sobre a felicidade perfeita, no livro X, os limites destas relações humanas no interior da vida teorética parecem ficar bem restritos:

"o filósofo isolado preserva a capacidade de contemplar e ele é mesmo tanto mais sábio quanto mais ele contempla neste estado. Em dúvida é preferível para ele possuir colaboradores, mas ele não é menos o homem mais auto-suficiente". ${ }^{38}$

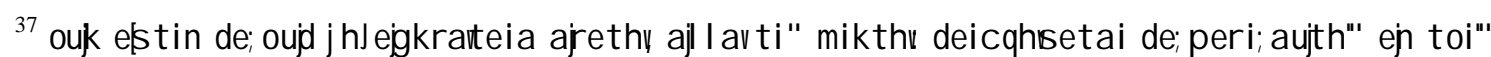
uईteron. nuh de; peri; dikaios unh" eipwmen (1128b33-35). Para Ramsauer, p. 280, e para Broadie, p. 334, a remissão à justiça é duvidosa, mas o resto apreende a essência do livro VII ; para Stewart, I p. 372, toda a passagem foi interpolada para os outros (Susemihl-Apelt ; Bywater ; Burnet, p. 201 ; Dirlmeier, p. 396 ; Irwin, p. 67 ; Bodeüs, p. 233), a passagem inteira é autêntica.

${ }^{38}$ olde; s of 0," kai;kaq jaut on wh dunat ai qewreih, kai; $\$$ w/ah s of wter 0 " hx mall on: bevtion d jiß w" sunergou," ek wn, a Jl joknw" a uf arkest at o" (1177a 32-b1). Ramsauer, p. 691, observa a bom título que o alargamento da autarkeia aos philoi na EN I 6 está baseado no fato que o homem é anêr politikos. Dirlmeier, p. 590, realça o fato que esta passagem concorda com uma outra passagem, 
A philia enquanto elemento da vida feliz, sobretudo do modo como é descrita nos livros VIII-IX da EN, parece encontrar seu lugar principalmente no bios politikos; poderse-ia pensar, com certeza, empregando os termos dos livros VIII-IX, que o contemplador do livro X poderia ter uma teleia philia com os sunergoi mencionados, isto é, com os colaboradores. Outras alusões às relações de philia entre filósofos aparecem em algumas passagens iniciais, nas quais há diversas alusões aos philo $i$ visto sobretudo como auxiliares e colaboradores (1097b10, 1112b28). Esta observação, porém, ainda que verdadeira, não daria conta do esforço analítico das diferentes formas de philia e da atenção às relações humanas que Aristóteles desenvolve nos livros VIII e IX, pois o contemplador não terá necessidade de todas as formas de amizade discutidas nestes livros.

Quanto ao termo philia, ele surge em II 4 1105b22, onde aparece na lista das pathê: aqui, portanto, philia, enquanto pathos, deve designar o sentimento de amizade que é mencionado mais adiante, em VIII 7, quando é denominado antes de philêsis:

"A philêsis parece ser um pathos, a philia é uma hexis". 39

Ao contrário, a philia enquanto hexis, discutida em EN VIII-IX, faz parte da série das virtudes. Aristóteles aborda este ponto em EN II 7, onde diz que:

"no que toca às relações agradáveis da vida, o homem agradável como convém é philos e a boa medida é a philia; quem cai no excesso... é um homem complacente [ou] um bajulador; quem peca pelo defeito... é rabugento e espírito ranzinza". ${ }^{40}$

EN IX 1170a6 : a atividade do homem feliz sera mais contínua exercida com outros »; mas o sentido das duas notas é oposto : $E N$ IX sublinha o fato que o homem feliz é mais plenamente feliz se tiver amigos ; $E N \mathrm{X}$, ao contrário, insiste sobre a capacidade do contemplador de cuidar de si mesmo. Compreendem bem Tricot, p. 510, Broadie, p. 442, Bodeüs, p. 526. Irwin, p. 307, apóia-se na expressão malista, 1177a28, para sustentar que a vida contemplativa não é completamente autarches, mas o é somente de modo limitado, porque não respeita as condições postas no livro I; porém, a interpretação parece um pouco forçada, visto que, na linha 1177b1, Aristóteles chama o contemplador de autarchestatos.

${ }^{39}$ ebiken d jhJmen fikhsi" paqei, hJde;filia exei (1157b28-29). Cf. Burnet, p. 89, que remete à classificação acadêmica contida nos Top. 126a 13. É um sentimento desinteressado de prazer quando alguém outro possui bens, Rhet. 1381a 4. Dirlmeier, p. 309, põe bem em evidência as hesitações de Aristóteles : em II 4, não há alusão à virtude da philia discutida em II 7 e IV 12, ao passo que o ponto de vista da EN VIII-IX é o da vida social e não o das pathê. Um problema que se pode pôr, acrescenta Dirlmeier, é o do elo entre philia e os sentimentos humanos fundamentais de philein e misein. Assim, ele observa que Aristóteles não resolveu todas as ambigüidades do conceito de philia. Em seguida, na p. 387, Dirlmeier observa que a $E E$ está de acordo a II 7 e não a IV 12. Irwin, p. 23, traduz philia em 1105 b 22 diretamente por "love"; Rowe por "friendly feelings", in Broadie, p. 115, p. 115; Bodeüs, por "amour", p. 110.

${ }^{40}$ peri;de;t o;l oip on hlu;t o; en twybiw/olmen wl" dei'hdu," wh filo" kai;hJmes oth" filia, old j uperball wn... alesko", ... kolvax, o]d je] leipwn... dus eriv ti" kai;duskol o" (1108a 23-30). 
A descrição da virtude da philia que encontramos no livro IV 12 1126b101127a12 não apresenta diferenças notáveis em relação à passagem de II 7; Aristóteles acrescenta somente que esta virtude está ligada à cortesia nas relações sociais e que, a bem dizer, seria anônima, mas como é semelhante à philia, pode-se designá-la pelo mesmo termo (ohoma de;ouk ajodedotai a uf hy ebiken de; mavist a $\mathrm{fil} i$ a); isso poderia levar a pensar que Aristóteles não reconhece esta virtude como uma philia verdadeira e própria. ${ }^{41}$ Parecenos interessante observar que, nestas passagens, philia é um termo utilizado para designar somente as relações de afeição e de afabilidade entre homens adultos dotados de direitos políticos, isto é, entre concidadãos. Com efeito, em 1097b8-11, os philoi são distinguidos do pai e da mãe, dos parentes próximos como mulher e filhos, e da esfera mais geral dos concidadãos. É uma diferença importante em relação à noção mais vasta e omnicompreensiva de philia que encontramos nos livros VIII-IX.

Algumas indicações sobre a relação dos livros VIII-IX com o que precede são fornecidas pelo capítulo inicial do livro VIII, no qual Aristóteles se aplica a mostrar a importância e o interesse da discussão da philia no campo de um logos êthikos. Aristóteles argumenta em prol do fato que a amizade é um bem, mostrando inicialmente que ela é um bem instrumental anagkaiotaton para a felicidade (1155a2-16) ${ }^{42}$ e, em seguida, mostrando que ela é também um bem em si, isto é, que é não somente anagkaion, mas também kalon (1155a28-30). ${ }^{43}$ Foi dito que, ao fazer isso, Aristóteles põe o capítulo VIII 1 no mesmo plano que I 3, no qual é introduzida a discussão sobre as virtudes em geral, VI 1, que introduz a discussão sobre a phronêsis, VII 1, que introduz a discussão sobre os estados reprováveis da alma (com fórmulas, como vimos, muito similares à de $E N$ VIII 1) e X 1, que introduz a

\footnotetext{
${ }^{41} \mathrm{O}$ melhor comentário sobre este ponto é o de Aspásio, p. 121, 7-9, segundo quem a philia aqui discutida é uma disposição subjetiva do homem virtuoso, diferente seja so sentimento de afeição, seja do elo entre dois indivíduos, o qual foi descrio nos livros VIII-IX; Bodeüs traduz o termo por "amabilité", p. 124 e 212. Broadie-Rowe, p. 309, partem deste elemento para distinguir a "friendliness" do livro II da «friendship » dos livros VIII-IX. Ver também Ramsauer, p. 262-263, que sustenta que o pathos da philêsis é uma condição necessária da philia.

${ }^{42}$ Cf. M. Van Straaten - G. J. DeVries, Notes on the VIIIth and IXth Books of Aristotle's Nicomachean Ethics, Mnemosyne S. IV/XIII (1960), p. 194, contra Dirlmeier, in EN, p. 510, que compreende anagkaion como "inevitável".

${ }^{43}$ Gauthier, p. 600, sustenta que, aqui, Aristóteles não expõe suas idéias pessoais, mas as idéias difundidas sobre a amizade; é verdade que são idéias difundidas, mas isso não impede Aristóteles de as partilhar.
} 


\section{Journal of Ancient Philosophy Vol. II 2008 Issue 1}

discussão sobre o prazer. ${ }^{44}$ Nestes quatro casos, Aristóteles apresenta, como justificação, argumentos ligados à sua definição de felicidade, argumentos fundados sobre a natureza humana e argumentos relativos à função do bom legislador. Isso é verdade, mas não é ainda suficiente para explicar por que Aristóteles quis dedicar uma parte tão grande da $E N$ a este bem em particular. Devemos agora somar os dados recolhidos e tentar obter algumas conclusões.

7. Conclusão e hipóteses finais. Natureza parcialmente independente dos livros sobre a amizade.

Uma hipótese provável, ou que nos parece assim, poderia ser a de que Aristóteles decidiu dedicar um texto tão longo à análise da amizade porque Platão o tinha feito, sobretudo no Lysis, diálogo do qual Aristóteles retoma algumas idéias em EN VIII-IX e contra o qual ele entra resolutamente em polêmica a respeito dos pontos fundamentais. É igualmente possível, como muitos críticos sugerem na trilha de von Arnim ${ }^{45}$, que a amizade tenha sido uma questão discutida também na Academia e que muitas aporias que Aristóteles discute em EN VII-IX provêm deste meio. Porém, a importância predominante da discussão platônica do Lysis não pode ser posta em questão.

Os dados textuais, em sua complexidade e contradição, poderiam nos induzir a partilhar a opinião de Stewart $^{46}$ segundo a qual estas páginas, embora tenham constituído durante um certo tempo um tratado autônomo, foram revistas para serem colocadas no contexto da EN. A revisão e o trabalho que consistiu em prover o texto de remissões adaptadas aos livros iniciais parecem, porém, concentrar-se na parte final da obra, no que é hoje o livro IX, ao passo que não tocaram o corpo central da análise, o livro VIII. Se quiséssemos nos engajar na via das hipóteses, poderíamos pensar que a segunda parte (= o livro IX) do logos peri philias foi fortemente revista no momento da inserção deste logos na $E N$ e, em conseqüência, é nela que ficou concentrado o conjunto de remissões aos livros I e III (a notar a ausência de remissões aos livros centrais, V-VII).

\footnotetext{
${ }^{44}$ Pakaluk, p. 45-46

${ }^{45}$ H. von Arnim, Die drei aristotelischen Ethiken, S-B d. Ak. d. Wiss. in Wien, Phil.-Hist. Kl., 202 (1924), p. 111.

${ }^{46}$ Stewart, p. 262.
} 
Neste momento descobre-se por que razão o discurso de Aristóteles sobre a amizade tem tanta amplitude. ${ }^{47}$ Nas obras de Platão, tanto no Lysis quanto no Banquete, a discussão estava centrada nas relações de afeição entre cidadãos homens e adultos ou entre jovens e homens mais maduros. Toda a esfera das relações familiares, de parentesco, de grupos sociais como as "fratrias" e os thiasoi fica fora da preocupação de Platão. Também, a vasta esfera das relações comerciais e de troca de serviços contra moeda não é examinada por Platão, enquanto Aristóteles o faz. Ademais, Platão mostra uma desconfiança evidente contra todas as formas sociais intermediárias, em direção aos tipos de relações próprias ao que poderíamos definir, com certo anacronismo, a "sociedade civil" da antiga Atenas, como as relações familiares e as relações de "clientela" social. Em suas obras políticas, como a República e as Leis, Platão tende a eliminar todas estas formas sociais ou pelo menos a submetê-las tanto quanto possível ao governo político. ${ }^{48}$ Portanto, ele não demonstra interesse em examinar em que sentido se toma a philia entre pais e filhos, entre marido e mulher ou entre amigos ricos e pobres. Quando, na República, Platão cita o provérbio pitagórico koina ta tôn philiôn, ele entende por philoi somente os homens solteiros ou as mulheres masculinizadas. Aristóteles, como se sabe, reagiu asperamente contra as posições de Platão na Política, tanto fazendo da família a primeira forma de comunidade natural (livro I) como criticando explicitamente a constituição da República e das Leis (livro II). Contudo, ele não se limita a isso; na $E N$, com a noção de "amizade que supõe uma superioridade de um dos membros", Aristóteles se dá um potente instrumento analítico para descrever todas as formas de relação que Platão havia negligenciado e queria eliminar como maléficas. Assim, Aristóteles pode também mostrar o bom comportamento entre elas e as formas de comunidade são recuperadas do ponto de vista "moral".

O fato que Aristóteles tenha desejado esboçar uma análise das relações não hostis de toda a sociedade civil de seu tempo, especialmente do mundo do oikos, contra a condenação platônica de toda esta esfera, é evidente na vasta discussão das relações de justiça entre philoi, na qual se encontra uma análise dos diferentes tipos de constituição política e

\footnotetext{
${ }^{47}$ O problema está bem posto por Fraisse, p. 203; mas não cremos que o alargamento da significação do termo philia que encontramos em Aristóteles em relação a Platão é uma volta ao sentido mais antigo de termo relativamente a um «progresso » que teria sido marcado por Platão.

${ }^{48}$ Cf. Nossa comunicação sobre "L'élision de l'oikos dans la Répubique de Platon" em curso de impressão nas atas do seminário dirigido por M. Dixsaut na Universidade de Paris 1.
} 


\section{Journal of Ancient Philosophy Vol. II 2008 Issue 1}

uma tentativa de comparação entre as relações familiares e a relações políticas. As relações familiares são justificadas com base na política - com uma aplicação irônica da correspondência platônica entre macrocosmos e microcosmos, entre polis e alma humana - de modo que a cada relação familiar corresponde por analogia uma relação política (por exemplo: pai : filho $=$ rei : súdito). Isto permite a Aristóteles explicar tanto o bom funcionamento da família como dar conta, com sua teoria das constituições corrompidas, das querelas familiares. A analogia entre a conclusão de EN IX e Metafísica XII, com a citação de falas de poeta, é uma indicação a mais, como se fosse necessário, da natureza parcialmente independente deste logos peri philias, que, como Metafísica XII, se mostra adaptado ao contexto de uma obra mais vasta, sem perder, porém, certos traços da autonomia de sua concepção original. Neste logos peri philias, Aristóteles expandiu as balizas de sua análise ética a uma série de relações diferentes das que se instauram entre cidadãos masculinos, ele deu expressão a toda uma esfera de experiência de vida negligenciada por seu mestre e ele buscou escrever um Lysis mais completo e as Leis menos totalitárias. Este elemento pode nos levar a formular uma conjetura sobre a origem da reunião de logoi que conhecemos como EN. Platão tinha dedicado aos diferentes problemas éticos uma série de diálogos distintos: a República sobre a justiça, o Lysis sobre a amizade, o Protágoras, entre outras coisas, sobre a coragem, o Mênon sobre a ensinabilidade da virtude e assim por diante. Xenofonte, de seu lado, tinha reunido em uma única obra, os Memoráveis, todas as discussões socráticas de caráter ético, organizando-as em um conjunto quase sistemático.

Aristóteles pode ter tido a idéia de fazer a mesma coisa, mas em um nível mais elevado do que aquele atingido por Xenofonte, buscando dar uma sistematização orgânica aos diferentes temas éticos mediante dois golpes decisivos: primeiramente, começar com uma definição geral, exata, mas ainda pouco clara, do bem humano supremo; depois, organizar toda a sua discussão por referência a esta definição. Com efeito, a definição da felicidade é citada em cada uma das articulações principais da obra e orienta parcialmente a seqüência; a análise das virtudes, tanto ética quanto dianoética, a análise das formas deficientes de caráter, a análise da amizade, do prazer, da felicidade perfeita e a análise do modo de pôr em prática os ensinamentos éticos. De um modo ou ouro, todas estas discussões se referem às definições do bem supremo e da felicidade que foram dadas no início. ${ }^{49}$ Deste modo, Aristóteles unifica

\footnotetext{
${ }^{49}$ Sobre este ponto, ver também Sarah Broadie, Ethics with Aristotle, Oxford 1991, p. 29.
} 
seu discurso com elos conceituais bem ligados a um ponto fundamental de sua teoria. Em sentido inverso, em todos os desenvolvimentos particulares surge fortemente a tendência de dar a cada investigação um movimento independente particular. Portanto, para além do quadro teórico de referência geral, Aristóteles procede em cada investigação de modo parcialmente autônomo. Daqui provêm, se nossa hipótese for exata, as características contrastadas dos livros da $E N$ de um lado, o fato que eles parecem estar ligados a um projeto geral; de outro, o fato que eles são realmente independentes na realização de seus objetivos particulares.

Referências Bibliográficas

Arnim, H. von Die drei aristotelischen Ethiken, S-B d. Ak. d. Wiss. in Wien, Phil.-Hist. Kl., 2021924.

Berti, E. (ed.) Aristotele, Esortazione alla filosofia (Protreptico), Pádua 1966, Nápoles $1994^{2}$.

Berti, E. Il concetto di amlicizia in Aristotele, in AA.VV., Il concetto di amicizia nella storia della cultura europea, Merano 1995, p. 102-122.

Berti, E. La filosofia del primo Aristotele, Pádua 1962, Milão $1997^{2}$.

Berti, E. Le ragioni di Aristotele, Roma-Bari 1989.

Bodeüs, R. Aristote. Ethique à Nicomaque, tradução, apresentação, notas e bibliografia, Paris 2004.

Bodeüs, R. Contribution à l'histoire des oeuvres morales d'Aristote: les Testimonia, Revue Philosophique de Louvain 711973.

Bodeüs, R. Le philosophe et la cité, Paris 1982.

Broadie, S. Ethics with Aristotle, Oxford 1991.

Burnet, J. The Ethics of Aristotle, London 1900.

Bywater, I. On a lost dialogue of Aristotle, Journal of Philology I, 1869.

Cambiano, G. Il ritorno degli antichi, Roma-Bari 1988.

Croce, B. Filosofia della pratica, economica ed etica (1909), ed. M. Tarantino, Bibliopolis, Nápoles 1996 ("Edizione nazionale delle Opere di B.C.").

Dirlmeier, F, Aristoteles. Nikomachische Ethik, üb. u. komm., Berlin 1959.

Düring, I. Aristotle's Protrepticus. An attempt at reconstruction, Göteborg 1961.

Fraisse, J. C. Philia. La notion d'amitié dans la philosophie antique, Paris 1974.

Gauthier, R.-A. e Jolif, J. Y. L'Ethique à Nicomaque, intr. trad. e com., Paris-Louvain 1959, 1970².

Gentile, G. Genesi e struttura della società. Saggio di filosofia pratica, in Opere IX, Florença 1987. 
Gigon, O. Aristotelis Opera, edidit Academia Regia Borussica, Editio altera, III: Librorum deperditorum fragmenta, coll. O.G., Berlin - New York 1987.

Grant, A. The Ethics of Aristotle, London $1874^{3}$.

Magiri, Io. Corona virtutum moralium, universam Aristotelis... Ethicen exacte enucleans... adjecto ubique Aristotelis contextu graeco-latino... , ed. R. Walker, Oxford 1942 (original: Frankfurt am Main 1628).

Matteucci, N. La filosofia della pratica in Benedetto Croce, in E. Berti (ed.), Tradizione e attualità della filosofia pratica, Gênova 1988, p. 95-108.

Moore, G.E. Principia ethica, Londres 1903.

Morel, P.-M. Aristote. Petits traités d'histoire naturelle, trad., introd., notas e bibliog., Paris 2000.

Natali, C. Etica Nicomachea, trad. introd. e notas, Roma-Bari 1999, $2001^{3}$.

Natali, C. Le premier traité d'éthique. Remarques sur la nature et les desseins de l'Ethique à Nicomaque d'Aristote, in E. Vegleris, Cosmos et psychè. Mélanges em homenagem de J. Frère, Hildesheim 2005, pp 211-228.

Pakaluk, M. Aristotle. Nicomachean Ethics books VIII and IX, transl. and comm., Oxford 1998.

Ramsauer, G. (ed.) Aristotelis Ethica Nicomachea, Leipzig 1878.

Romeyer Dherbey, G. Vie bienheureuse et philosophie. Les traces du Protreptique dans le livre X de $l$ 'Ethique à Nicomaque (1975), in: La parole archaîque, Paris 1999, p. 200-220.

Rowe, Ch. The Eudemian and Nicomachean Ethics. A study in the development of Aristotle's thought, Cambridge 1971.

Stewart, J. A. Notes on the Nicomachean Ethics of Aristotle, Clarendon Press, Oxford 1892, repr. Bristol 1999.

Straaten, M. van e De Vries, G.J. Notes on the VIIIth and IXth Books of Aristotle's Nicomachean Ethics, Mnemosyne S. IV/XIII (1960).

Susemihl, F. (ed.), Aristotelis Etica Nicomachea, Leipzig 1882.

[Tradução de Marco Zingano; revisão de Alberto Rocha Barros] 